\title{
Challenges and Opportunities for Agribusiness Development: Lesson from Indonesia*
}

\author{
Soetriono SOETRIONO ${ }^{1}$, Djoko SOEJONO ${ }^{2}$, Evita Soliha HANI ${ }^{3}$, \\ Anik SUWANDARI ${ }^{4}$, Bagus Shandy NARMADITYA ${ }^{5}$
}

Received: July 03, 2020 Revised: July 19, 2020 Accepted: August 10, 2020

\begin{abstract}
This study aims to determine the technical aspects of organic food systems in rice agribusiness and analyze the pattern of economic and institutional structures of agribusiness in East Java of Indonesia. Also, this study investigates the feasibility of farming and understands the strategies of rice agribusiness development. This study was conducted in several places in East Java of Indonesia, covering the district of Blitar, Kediri, Bondowoso, Tulungagung, and Malang. The data were collected through a structured questionnaire and focus group discussion. Furthermore, the data were analyzed using efficiency analysis, revenues analysis, and SWOT analysis. The findings indicated that, technically, the district of Bondowoso, Malang, Kediri, and Tulungagung had implemented the organic systems, while the district of Blitar applied under semi-organic systems. The pattern of economic institutions of agribusiness commodity consists of the production facility, farming, post-harvest and product processing, marketing, and support services institutional. These results showed that the organic rice farming is economically viable, and the government support was provided in the form of the establishment of development centers, the facilitation of agricultural machines, integrated crop management field school, and the organic certification. These findings suggest that several places in East Java have prospective opportunities for production of rice agribusiness development.
\end{abstract}

Keywords: Organic Rice, Farmer Welfare, Development Strategic, Agricultural Sector

JEL Classification Code: H75, I31, O13

\section{*Acknowledgements:}

The highest appreciation provides to the research and development of East Java provincial and LP2M University of Jember for facilitating the completion of this project

${ }^{1}$ First Author and Corresponding Author. Faculty of Agriculture, University of Jember, Indonesia [Postal Address: Jalan Kalimantan

No. 37, Kampus Bumi Tegal Boto, Krajan Timur, Sumbersari,

Kabupaten Jember, East Java, 68121, Indonesia]

Email: triono.faperta@unej.ac.id

${ }^{2}$ Faculty of Agriculture, University of Jember, Indonesia.

Email: soedjono_djoko@faperta@unej.ac.id

${ }^{3}$ Faculty of Agriculture, University of Jember, Indonesia.

Email: ita_hani.faperta@unej.ac.id

${ }^{4}$ Faculty of Agriculture, University of Jember, Indonesia.

Email: aniksuwandari@gmail.com

${ }^{5}$ Faculty of Economics, Universitas Negeri Malang, Indonesia.

Email: bagus.shandy.fe@um.ac.id

(c) Copyright: The Author(s)

This is an Open Access article distributed under the terms of the Creative Commons Attribution Non-Commercial License (https://creativecommons.org/licenses/by-nc/4.0/) which permits unrestricted non-commercial use, distribution, and reproduction in any medium, provided the original work is properly cited.
ontestricted non-commerial use,

\section{Introduction}

In the global economy, most developing countries face several structural problems in production and consumption systems (Clark, 2007; Akenji \& Bengtsson, 2014; Govindan, 2018). Besides, the literature mentions that the developing countries are associated with food security issues, poverty, unemployment, and quality of education (Larson et al., 2007; Etana \& Tolossa, 2017; Rachmawati et al., 2018). However, since the nation confronted a trade-off due to scarcity, it forces the government to prioritize the sector to be addressed. Some evidence suggests that increasingly prioritize food, and agricultural affairs will lead to higher welfare, even by implementing protection strategies that tend to be overrated (da Silva et al., 2018; Inwood, 2017).

The success and failure of the government policy in agriculture sectors can be seen by the enhancement of farmer's wellbeing (TerAvest et al., 2019; Sedyati et al., 2019). The development of agriculture is not merely oriented towards increasing the physical production of 
various agricultural commodities, plantations, livestock, and fisheries. The criteria for success should be measured by improving the level of income of farm households, increasing labor productivity, and improving macro- indicators such as reducing poverty and unemployment (Olowu et al., 2019). In Indonesia's context, the government has set a long-term goal to accomplish community welfare (Thufail, 2016). It consists of several efforts for improving the ability of farmers and their supporting institutions, securing food security, increasing productivity, production and competitiveness of agricultural products, and supporting forests for business diversification and support food production (Amrullah et al., 2019).

The availability of food in sufficient quantities, adequate quality, and affordable prices by the population are some of the targets to be achieved in the formulation of national food policies. Food supply instability, volatile food prices (rice) in Indonesia have been proven to trigger social instability (O'connor et al., 2017; Wildana \& Alhabshi, 2018). Food security is a condition of fulfilling food for households, which is reflected in the availability of sufficient food, both in quantity and quality, safe, equitable, and affordable. The approach of the framework for the study of food security and nutrition of the community is focused on exploring aspects of food fulfillment by the community, the level of food availability, and food accessibility and stability (Saediman et al., 2019).

Healthy lifestyles and green behavior have become a new trend, and leave the old lifestyle that uses non-natural chemicals, such as fertilizers, synthetic chemical pesticides, and growth hormones in agricultural production (Rana \& Paul, 2017). Such a healthy lifestyle has been institutionalized internationally, which requires a guarantee that agricultural products must have food safety attributes, high nutritional attributes, and eco-labeling attributes (Hasanah et al., 2019). These attributes are closely attached to organic agricultural products. Organic farming is a solution to restore the health of the land and the products produced (Marja et al., 2020). The people's desire to switch to organic products causes the demand for organic agricultural products to increase rapidly. Organic agriculture producers in East Java currently are still minimal. This is an opportunity for agribusinesses to develop organic food products. For this matter, this organic food phenomenon needs to be captured as an opportunity for agricultural development in East Java, especially regarding strategic food products.

The application of organic systems to food commodities, especially rice, is still a dilemma between efforts to increase production by using fertilizers or chemical pesticides as well as efforts to preserve nature that tries to control the agrochemical products (Ali et al., 2019). Organic rice agribusiness with high costs and based on some shortcomings do not cause all parties to provide support to organic agriculture. Organic agricultural products are currently only being enjoyed by certain groups, namely, the middle to the upper-class economy, because the price is more higher than conventional agricultural products (Kim et al., 2014; Altarawneh, 2016). Another obstacle to organic agriculture is related to the condition of food needs that are still importing food, so it needs better thinking when implementing organic agriculture to produce healthy, affordable, and adequate food products for East Java. For these reasons, this research is focused on the prospect of organic rice agribusiness development to support the food security program in East Java, which covers the technical and implementation of organic food systems, economic structures, and institutions, the feasibility of farming and strategies for developing organic rice commodity agribusiness.

\section{Literature Review}

Success and failure in the agricultural business are determined by managing the farming business (Purwanti et al., 2020). A farmer as a manager is someone who plays a role in planning business activities that include the provision and allocation of funds (Sedyati et al., 2019). A farmer who is aware of the purpose of the business and management of advanced farming has an excellent chance of obtaining profit in the agricultural sector. This is due to the fact that every decision will influence business performance. Furthermore, the farmers will estimate how much the gross yield of production is the area of the land multiplied by the results per unit area, which is then valued in money (Kuswanto et al., 2019). The results must be reduced by the costs incurred during the production process; then, the farmers will receive what is called net yield.

Also, the production cost is crucial, which affecting business performance. Production costs can be divided into two groups: fixed costs and variable costs (Deo et al., 2018). Fixed costs are big or small and are not influenced by the size of the production, such as land rent and land tax. Meanwhile, variable costs are the size of which is influenced by the size of the production, such as expenditure on fertilizer purchases and labor costs. Lastly, the total costs are the sum of fixed costs and variable costs. Soekartawi (1995) remarked that in farming, revenue (gross income) is a multiplication of physical production with the selling price or production price. In addition, according to Mankiw (2020), the total revenue is equal to the number of output units multiplied by the price of output per unit. Net income or profit is the difference between revenue and all costs.

The principle of optimizing the use of factors of production is how to use the factors of production efficiently. Soekartawi (1995) pointed out that the notion of efficiency in economics is classified into three: technical efficiency, price efficiency, and economic efficiency. The use of production 
factors is stated to be technically efficient if the production factors used can produce maximum production. Producers acquire a significant profit from their business activities; for example, since the influence of prices, the producers can be stated to allocate their production factors in a price efficiency. Price efficiency is achieved when the value of marginal products is the same as the price of the factor of production concerned. Lastly, economic efficiency occurs when efforts are made to achieve technical efficiency as well as price efficiency (Guesmi et al., 2018; Anik et al., 2020).

Efficiency is an effort to achieve goals by using the minimum amount of resources. Efficiency is associated with the comparison of costs (sacrifice) with output or results (Abdulai \& Abdulai, 2017). The efficiency of production costs can be measured by $\mathrm{R} / \mathrm{C}$ ratio analysis, which is the ratio between revenue and production costs. The $\mathrm{R} / \mathrm{C}$ ratio value shows the amount of income received for each rupiah spent on production. The high value of the $\mathrm{R} / \mathrm{C}$ ratio is caused by the production obtained and the price of commodities, which is very influential on the acceptance of farmers as entrepreneurs. The value of the $\mathrm{R} / \mathrm{C}$ ratio is strongly influenced by the amount of revenue and the total costs incurred by each farmer. The $\mathrm{R} / \mathrm{C}$ ratio value is higher than one, which means that in various business scales, the business is economically efficient and feasible to be developed (Utami \& Dian, 2019).

In analyzing business, the SWOT analysis is carried out based on the assumption that an effective strategy will maximize strengths and opportunities, and minimize weaknesses and threats. If applied correctly, simple assumptions have substantial implications for designing a successful strategy (Pearce et al., 2000). The description of the interpretation of the SWOT analysis can be explained as follows: first, the strength of the company that illustrates the magnitude of the benefits of resources and its progress in supporting change; second, the weakness of the company that reflects the limitations of resources and the company's ability to severely hinder the company's compelling performance in developing operations strategies; third, company opportunity that illustrates the company's favorable situation so that it creates opportunities and opportunities; lastly, threats that describe the company's situation that is not profitable for the company so that it creates challenges, threats and obstacles (Lambin et al., 2007).

According to Rangkuti (2001), the SWOT analysis is the systematic identification of various factors to formulate a company's strategy. This analysis is based on the logic that can maximize strengths and opportunities but simultaneously can minimize weaknesses and threats. The strategic decisionmaking process is always related to the development of the company's mission, goals, strategies and policies. Thus, strategic planning must analyze the company's strategic factors (strengths, weaknesses, opportunities and threats) in the current conditions.

\section{Research Methods}

This study combined an analytic, descriptive and correlational method to comprehensively understand the existing phenomenon (Cresswell \& Clark, 2017). The technique of collecting data uses the method of squential sampling, namely, by drawing a small sample randomly and analyzing it (Nazir, 2005). The small sample analysis determines the subsequent withdrawal of the sample size. The number of samples in this study will be adjusted to the conditions at each study location. Data collection techniques are done through structured interviews. Data collection prepares research instruments in the form of written questions for which alternative answers have been prepared. The study was conducted in several places such as in the district of Blitar, Kediri, Bondowoso, Tulungagung and Malang. The fundamental reason is that the region has the potential to develop rice commodities and farmers in the area are seeking organic rice both individually and in groups (Soetriono et al., 2017). Furthermore, the data were analyzed accordingly using descriptive analysis, efficiency analysis, and SWOT analysis.

The analytical method employed includes descriptive and efficiency analysis (Soekartawi, 1996).

$$
\pi=T R-T C
$$

Information:

$\pi=$ Revenue $(\mathrm{Rp})$

$\mathrm{TR}=$ Total revenue $(\mathrm{Rp})$

$\mathrm{TC}=$ Total cost $(\mathrm{Rp})$

Decision Making Criteria:

- TR $>$ TC, then organic rice farming benefits farmers

- TR $<\mathrm{TC}$, then organic rice farming impedes farmers

- $\mathrm{TR}=\mathrm{TC}$, then organic rice farming breaks even (break event point)

To test the second hypothesis about cost efficiency in organic rice farming, analytical method is used.

$$
R / C \text { ratio }=a=\frac{R}{C}
$$

Decision Making Criteria:

- $\mathrm{R} / \mathrm{C}$ ratio $\leq 1$, then the use of production costs in organic rice farming is inefficient.

- $\mathrm{R} / \mathrm{C}$ ratio $>1$, then the use of production costs in organic rice farming is efficient.

For the next problem, SWOT analysis is used in several stages (see Table 1). Identify internal and external factors for the development of organic rice, Internal Factor Analysis Summary (IFAS) and External Factor Analysis Summary 
(EFAS). Internal factor analysis includes identification of strengths and weaknesses; external factor analysis includes identification of opportunities and threats (Rangkuti, 2001).

To determine the relative competitive position, a matrix consisting of Ideal quadrants (high growth/high competition); adult (low growth/high competition); bad (low growth/low quality); speculative (high growth/low competition is used. Then to choose and make strategies is by combining internal elements with external in the form of a SWOT matrix (see Table 2).

\section{Results and Discussion}

\subsection{Technical and Application of Organic Food Systems at Local Level}

\subsubsection{The District of Bondowoso}

The application of organic rice in the district of Bondowoso was conducted through several stages. The technical and application of rice cultivation in organic farms usually begin with the selection of seeds or seeds non-hybrid. In addition to maintaining biodiversity, technically possible non-hybrid seeds can live and produce optimally on natural conditions. Natural varieties of rice that can be selected to be grown organically are Rojolele, Mentik, Pandan, and Cianjur. Seeds used in producing organic food in the organic food system were the seed without treatment or were not derived from genetically modified products. Organic rice production, which was managed by farmers, has increased rapidly. The average rice production was currently around 5.7 tons per ha. Meanwhile, the results of tile in several places that were already using organic fertilizers with hybrid varieties reached an average of 10 tons per ha. Therefore, the farmers have opportunities to improve the quality and the quantity of rice productivity around 4.3 tons or about $75 \%$ per hectare. Another advantage that was gained by the farmers through Botanic system, if before the farmers sold the inorganic rice as much as Rp8,000 per kilogram, then by producing the organic rice the farmers can sell organic rice for Rp13,000 per kilogram, so that farmers gain Rp5,000 higher for each kilogram.

\subsubsection{The District of Malang}

In Malang, for example, in the District of Lawang, there is a farming community trained by the Agriculture Department of Malang, which is already producing organic food such as white rice, red rice, and black rice. At first, some farmers only tried on one hectare of land belonging to one of the farmers in the headwater sources that are located far enough from the settlement. Then the purpose of this is that the rice will not be contaminated by pesticides carried by water. At the first trial, the results were less satisfactory. Land that should be able to produce five tons of rice with the chemical fertilizers was only able to produce 2.6 tons of rice were just using mulch and blotong (solid waste which able to be re-used). In order to solve this issue, the farmers in the village of Sumber Ngepoh combined the use of $75 \%$ urea and $25 \%$ organic fertilizer. The use of urea fertilizer was reduced by $25 \%$ each year, and organic fertilizer using was increased until finally, they have used pure organic fertilizer since 2001. Currently, the harvest is, on average, 6-7 tons per hectare.

Table 1: Elements of SWOT Analysis

\begin{tabular}{|c|c|}
\hline $\begin{array}{c}\text { S (Strength) } \\
\text { What the main strengths of } \\
\text { Organic rice business } \\
\text { (Internal) } \\
\text { (from the past to present) }\end{array}$ & $\begin{array}{c}\text { W (Weakness) } \\
\text { O (Opportunity) }\end{array}$ \\
$\begin{array}{c}\text { What the main weaknesses of } \\
\text { Organic rice business } \\
\text { (Internal) }\end{array}$ \\
(from the past to present)
\end{tabular}

Table 2: SWOT Matrix for Formulating Strategies

\begin{tabular}{|l|l|l|}
\hline \multicolumn{1}{|c|}{ IFAS } & \multicolumn{1}{|c|}{ Strengths (S) } & \multicolumn{1}{c|}{ Weaknesses (W) } \\
\hline Opportunities $(\mathrm{O})$ & $\begin{array}{l}\text { SO Strategy } \\
\text { (Creating strategies that use power to } \\
\text { take the advantage of opportunities) }\end{array}$ & $\begin{array}{l}\text { Strategy WO: } \\
\text { (Creating strategies that minimize } \\
\text { weaknesses to take the advantage of } \\
\text { opportunities) }\end{array}$ \\
\hline Threats $(\mathrm{T})$ & $\begin{array}{l}\text { Strategy ST } \\
\text { (Creating strategies that use power to } \\
\text { overcome threats) }\end{array}$ & $\begin{array}{l}\text { Strategy WT } \\
\text { (Creating strategies that minimize the } \\
\text { weaknesses and avoid threats) }\end{array}$ \\
\hline
\end{tabular}




\subsubsection{The District of Blitar}

There are many restrictions on the organic farming system, but in principle, the organic farming system aims to manage the agricultural land ecologically by increasing biodiversity, biological cycles of soil biological activity by using the material from outside and to improve the harmony of ecosystems. Through this system, the expected productivity in the form of quantity and quality is maintained, the resulting products are healthy and safe for the consumers. Moreover, the quality of the environment is maintained. One of the districts is Blitar; the communities began to realize the importance of organic food consumption, especially rice. Blitar is an East Java agricultural cantilever capable of producing harvesting and planting activities three times a year. It is because the total farming that is optimized in the district of Blitar reached 500 ha.

\subsubsection{The District of Tulungagung}

It was starting from a situation that had miserable air pollution and the use of chemicals in fertilizers and pesticides. It may damage the soil condition, which causes the reduction of nutrients in the soil. Currently, the condition of the nutrients contained in the farmland surrounding Tulungagung is only $1 \%$. While the land includes infertile land, if the nutrients reach $4-5 \%$, such conditions lead to the declining harvest. Declining harvest means that it will decrease the welfare of farmers in Tulungagung. In Tulungagung, there is a group called Grasia (Gerakan Anak Indonesia, in the Indonesian language) that builds an organic rice development program in the Tulungagung subdistrict, especially in Wates Sumbergempol village. In the early stages, this movement focused on human resource development to grow independence and high bargaining power, which relied on the environment and led to the improvement of farmers' welfare. The group activities are including rice cultivation and ornamental plants. Before planting organic rice started, held the survey to review the natural pesticides, stabilization of home composting, and the preparatory of the Legowo jajar planting system. Moreover, designed budget also includes the rice buying from the farmers, training, packaging, and assessment of Sucofindo. It is estimated that the rice harvest per hectare is as much as $2,200 \mathrm{~kg}$ with the selling price of rice Rp35,000 per $2 \mathrm{~kg}$.

\subsubsection{The District of Kediri}

In Kediri, there is one group of farmers who produce organic rice. Organic rice is rice produced through the natural processes, from the initial planting, processing until the rice is ready for consumption, $100 \%$ do not use chemical pesticides. Planting and eradication of pests use the compost and green manure, which is fermented naturally. The Farmers Group, who has managed to produce organic rice, is in the Sumber
Pancur, Kepung Village Kepung District. This group has a land area of 5 hectares. All production processes that are carried out by Farmers Group Cultivation do not use chemical fertilizer but using organic fertilizers from goat manure.

\subsection{The Pattern and the Structure of Rice Agribusiness at the Local Level}

\subsubsection{The Institutional of Production Facilitation on Organic Rice Cultivation}

Investment in an economic system has a strategic role in agricultural development. One form of the investment needed in the development of organic rice is institutional production medium. Organic farming in five districts in their management process does not use fertilizers and pesticides, which are made from chemicals, but they use organic materials. Organic farming uses inputs such as seeds were used little, organic fertilizers and organic pesticides. Organic farming supports the farmers to be more independent because it can create its production facilities using the organic ingredients that are easily obtained. Such as agricultural waste as fertilizer and the plants around the environment as a pesticide plant. The benefits of organic farming can also reduce production costs, and farmers can increase their income.

\subsubsection{Institutional Farming/Production}

The development of organic rice is managed collectively under an institution, either farmer community or agricultural cooperatives. The economic institutions, which are based on general farmer groups, have the strength to survive. However, this farmer group institution has limited capital services ability to serve its members. Generally, the suppression activities of farmers groups precisely are not to give the waiter capital of its members but to provide the collective resource management (e.g., water and planting schedules) and social life.

\subsubsection{Institutional of Post-Harvest and Result Processing}

Institutions are needed to rescue the post-harvest selling price of the organic rice harvest in order to prevent a sharp decline during the harvest. Post-harvest institutions are expected to collaborate with the organic rice farmers because, in each region, there have been no research institutions that specifically deal with this field. Generally, post-harvest activities are handled by the farmers, or managed by farmer groups. Post-harvest institutions functioned as a manager in terms of organizing, preparing the human resources, and supporting the infrastructure facilities. 
Table 3: Revenue Average of Organic Rice Farmers

\begin{tabular}{|l|l|c|c|c|c|c|}
\hline \multirow{2}{*}{ No } & \multirow{2}{*}{ Explanation } & \multicolumn{5}{c|}{ District } \\
\cline { 3 - 7 } & & Bondowoso & Malang & Blitar & Tulungagung & Kediri \\
\hline 1 & Production Average (kg/ha) & 7.192 & 7.698 & 5.582 & 6.714 & 8.098 \\
\hline 2 & Dry Grain Prices (Rp) & 5.000 & 5.000 & 7.000 & 4.800 & 4.400 \\
\hline 3 & Production Average (Rp/ha) & 13.651 .923 & 15.348 .113 & 17.160 .642 & 9.023 .571 & 14.181 .967 \\
\hline 4 & Revenue Average (Rp/ha) & 35.961 .538 & 38.490 .566 & 39.076 .305 & 32.228 .571 & 35.632 .789 \\
\hline 5 & Revenue Average (Rp/ha) & 22.309 .615 & 23.142 .452 & 21.915 .662 & 23.205 .000 & 21.450 .819 \\
\hline 6 & Average R/C & 5.08 & 4.66 & 4.44 & 4.83 & 4.38 \\
\hline
\end{tabular}

\subsubsection{Institutional Marketing}

Institutional marketing involves the institutional of organic rice trading system. That is started from the producer to the consumer. Organic rice has a comparative advantage because it has unique, organic rice. It resulted from the cultivation without using chemicals when compared with the rice in the market. Organic rice is healthier instead of non-organic rice. Besides, organic rice has a competitive advantage because the production is pure organic rice; thus, the rice flavored is better than other rice, therefore based on the service view, it will get consumer satisfaction. The role of institutions is to analyze marketing using market segmentation as a marketing method.

\subsubsection{Institutional Support Services}

Institutional services determine the success of a series of institutional systems built for the development of organic rice. The support service included in essential points is institutional of venture capital, the agricultural machine providers, and the institutional apparatus. Institutions in the field of capital and the need for capital in rural areas are perceived, especially for the working capital. Therefore, capital is significant to help the farmers economically, overcome the problem that emerges in the hard time or the need to manage the land, purchase the seeds, purchase fertilizers, and purchase the other farm tools. This institution is in the form of the company or producing industry and agricultural manufacture in the large, medium, and small scale, including the businesses that perform manufacture workshops and a simple producing machine scattered in rural areas. The Apparatus Institutional, the government, is as policymaker that has a strategic role in the development of organic rice in the central region, especially that is related to the dissemination of innovations through the counseling activities.

\subsection{Eligibility Level of Organic Rice Farming Commodities at the Local Level}

Table 3 provides information about the revenue average of organic rice of farmers. The average value of organic rice farming income in each district can be seen based on the table. The highest average production is in the district of Kediri, which amounted to $8,098 \mathrm{~kg}$ per ha. Meanwhile, in the district of Bondowoso, Malang, Blitar, Kediri, and Tulungagung have a value of $\mathrm{R} / \mathrm{C}$ ratio by $5.08 ; 4.66 ; 4.44$; 4.83 and 4.38 , respectively. It means that every Rp1.00 it can produce the amount profit of the $\mathrm{R} / \mathrm{C}$ ratio in each district. The value of the $\mathrm{R} / \mathrm{C}$ ratio is more than one indicates that the revenue generated by the organic rice farmers in the regency is higher than the expense. The high acceptance is influenced by the amount of production and the price of commodities of organic rice. Organic rice farmers in each district always consider the efficient cost for their organic rice farming.

\subsection{The Government Support and Stakeholders}

\subsubsection{The District of Bondowoso}

Implementation program in Bondowoso to organic farming began in 2009, and in 2013, the road map achieving showed the significant development, one of the enhancement was the Botanic Program (Bondowoso Organic Farming). The botanic program does not only grow rice, but also plants a milestone. That organic agriculture program was launched in 2009 in order to change the thinking of fertilizing plants to be fertilizing the soil. This concept is in accordance with the organic farming road map in Bondowoso. It should be integrated from the headwater to the downstream (water resources, agro-inputs, the farming system, and the harvest processing). The initial stage of socialization has been done using organic fertilizers. The use of organic fertilizers has reached 25,000 hectares, the next stage of the use of botanical pesticides, the agents of biological liquid organic 
fertilizer (POC). The final stage of organic farming activity is implementing organic agricultural production in the form of clusters and fulfilling the proper requirements for the institutional, the irrigation systems, and the facilities. It has been assisted for three years in a row with a program of integrated crop management field school (SLPTT).

\subsubsection{The District of Malang}

The role of stakeholders in the organic rice agribusiness is to conduct counseling to distribute new information, especially related to technology applications that are useful to farmers. One of the activities that are undertaken by the stakeholders is an application test of Organic Fertilizer. Other implemented programs to support the agribusiness organic rice harvest is the Dem Farm program. Through rice Dem Farm, the empowerment of farmers is an effort to facilitate the learning process for the farmer groups through the application of the technology of rice that have been tested. Thus, they can use their potential to increase the production and productivity of rice. Dem farm is one method of counseling conducted through the demonstration of farming by farmer community members in agricultural land in the area of 1-5 hectares per unit. The program aims to increase the productivity of rice plants in order to achieve rice self-sustainable.

\subsubsection{The District of Blitar}

Developing organic rice in Blitar, the government donated help in the form of agricultural machines, one of them is a water pump. Another effort undertaken by the government of Blitar is by conducting SLPTT (Integrated crop management field school). The effort made by the Agricultural Department in Blitar was by implementing the development of organic agriculture, especially rice. That was in the form of Help Task. Supporting factors of the Department of Agriculture effort in implementing the development of organic rice is the government's support in the form of counseling of organic farming systems to reach food self-sufficiency.

\subsubsection{The District of Tulungagung}

Currently, the district of Tulungagung also is determined to be a "pilot project" for the cultivation of organic rice from Japan, called "Jafonica" before it is being developed into other areas in East Java. Organic rice is the work of devotion farmer or agricultural counseling workers that were recruited since 2007 and based on law number 16 of 2006 on the counseling system in order to expand and improve selfsufficiency in rice. The government provides the counseling and the training program of organic farming planting in Apparat farmers who want to learn to plant and control the pest for free.

\subsubsection{The District of Kediri}

Rice commodity development in Kediri was more focused on Rice Agribusiness Development. The farmer community (Gapoktan) can afford to buy the rice from the farmers or farmer group members and later sold in the form of rice. Thus, from the production process to the products' marketing process, it involves the farmer community. Therefore, the benefit could be shared between farmers and farmer communities. Besides, to support the development of organic farming and to anticipate the decreasing in the sales price of organic rice, the government promoted rice storage in each village, which functions and systems that is similar with a warehouse receipt, to store grain farmers when the price is affordable, then selling it when the price is high.

\subsection{The Prospects and The Strategy for Agricultural Development}

The analysis of the strengths, weaknesses, opportunities, and threats of the agricultural development on organic rice commodities to support the food security in the five districts in East Java are provided in Figure 1.

First, the analysis showed that the SWOT analysis's relative competitive position is the IDEAL quadrant with a value IFAS and EFAS 3.16 and 3.48, respectively. It has a prospective opportunity, and the producers are keen on developing agriculture. From this result, the development of organic rice agribusiness can be enhanced by using the advantage of the potential resources and strengthening the cooperation between the farmer community with the local governments and other stakeholders. Also, it requires the existence of adequate incentive prices for organic products. In the Malang district, the relative competitive position of SWOT is the IDEAL quadrant with a value IFAS and EFAS 3.22 and 3.44, respectively. From the finding, the agricultural development can be conducted by increasing organic rice farming by optimizing facility and utilizing the support of the farmer community and the government. Furthermore, the practice of organic farming is needed to encourage market demand.

In the district of Blitar, it can be seen that the relative competitive position of SWOT is the DISTRESS quadrant with value IFAS and EFAS 1.71 and 1.69, respectively. This implies that agricultural development has a prospective opportunity, and the producers are not strong enough to develop it. Those can be enhanced by applying and developing the quality of intensification quality improvement of the irrigated land with an organic approach system. Second, the determination of organic rice development, which is supported by infrastructure. 
(a)



(c)

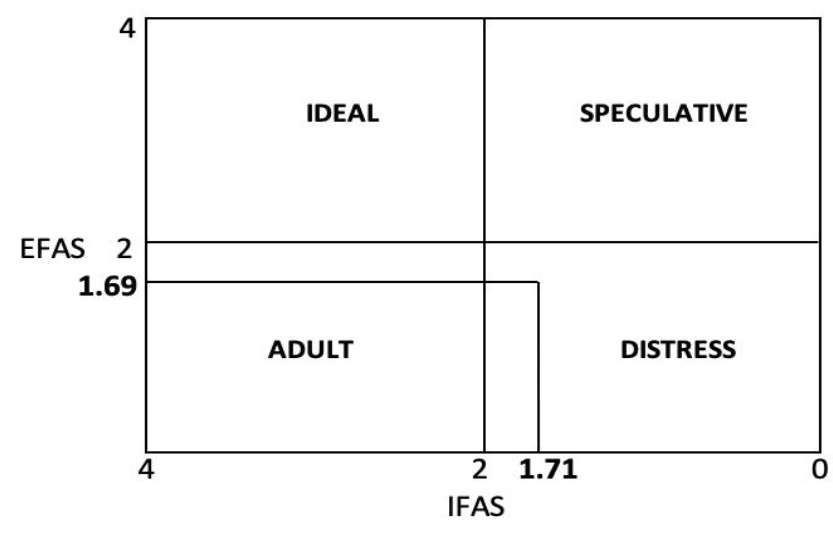

(b)



(d)

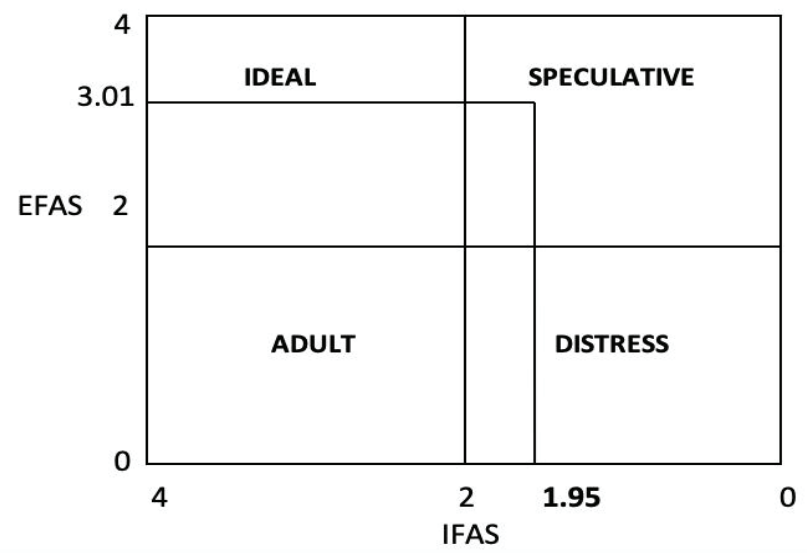

Figure 1: The Matrix Diagram of Competitive Position on Agricultural Development in East Java

Note: (a) the district of Bondowoso, (b) the district of Malang, (c) the district of Blitar, (d) the district of Kediri and Tulungagung

Accordingly, both the district of Kediri and Tulungagung have the same model (see point $d$ ). The figure shows that the relative competitive position of SWOT is the speculative quadrant with value IFAS EFAS 1.95 and 3.01. This means that the agricultural has the prospective opportunity, and the producers are not strong enough to develop it. From this result, both districts were required to enhance the product sales strategy through bonuses and discounts while considering the cost of production. Second, increasing the creativity of the products according to consumer preferences; and strengthening the institutions in order to have bargaining power against the market.

\section{Conclusions}

The previous explanation shows that the district of Bondowoso, Malang, and Tulungagung in rice farming activity has implemented the organic system and certified of LeSOS, and Tulungagung has implemented an organic system. However, it is still in the process of filing the certification, whereas in Blitar is still a semi-organic phase. The institutional pattern of economic development on organic rice agricommodities and organic semi consists of institutional of the production facility, farming institutional or production processes, institutional of post-harvest and harvest processing, and the institutional of product marketing; institutional of support services. The agribusiness activities of organic rice commodities are conducted under the farmer groups and Agricultural Cooperatives. The eligibility level of organic rice farming, the income approach shows that farming activities in Malang, Blitar, Kediri, and Tulungagung, are economically profitable and efficient in the use of cost. 
Furthermore, the support of government and stakeholders toward organic rice agribusiness in Bondowoso, Malang, Kediri, and Tulungagung is the formation of development areas, building facilities, road infrastructure and irrigation networks, access to the financial institutions, facilitation of certification, promotion of organic products, SLPTT. In Blitar, the agricultural machine aids are pumping, promotional products, and SLPTT. Lastly, prospects and agribusiness development strategy of organic rice in Bondowoso and Malang, organic rice commodities included to ideal quadrant, which means the development has good prospects. Blitar, organic rice commodities entered the distress quadrant; it means that development has a miserable prospect. Tulungagung and Kediri, organic rice commodities entered the speculative quadrant, which implies that the development has reasonably good prospects.

\section{References}

Abdulai, A. N., \& Abdulai, A. (2017). Examining the impact of conservation agriculture on environmental efficiency among maize farmers in Zambia. Environment and Development Economics, 22(2), 177-201.

Akenji, L., \& Bengtsson, M. (2014). Making sustainable consumption and production the core of sustainable development goals. Sustainability, 6(2), 513-529.

Ali, M. P., Bari, M. N., Haque, S. S., Kabir, M. M. M., Afrin, S., Nowrin, F., ... \& Landis, D. A. (2019). Establishing next-generation pest control services in rice fields: ecoagriculture. Scientific Reports, 9(1), 1-9.

Altarawneh, M. (2016). Determine the barriers of organic agriculture implementation in Jordan. Bulgarian Journal of Agricultural Science, 22(1), 10-15.

Amrullah, E. R., Ishida, A., Pullaila, A., \& Rusyiana, A. (2019). Who suffers from food insecurity in Indonesia?. International Journal of Social Economics, 46(10), 1186-1197.

Anik, A. R., Rahman, S., \& Sarker, J. R. (2020). Five Decades of Productivity and Efficiency Changes in World Agriculture (1969-2013). Agriculture, 10(6), 1-21.

Clark, G. (2007). Evolution of the global sustainable consumption and production policy and the United Nations Environment Programme's (UNEP) supporting activities. Journal of Cleaner Production, 15(6), 492-498.

Creswell, J. W., \& Clark, V. L. P. (2017). Designing and conducting mixed methods research. Thousand Oaks, CA: Sage Publications.

Da Silva, J. M. C., Prasad, S., \& Diniz-Filho, J. A. F. (2017). The impact of deforestation, urbanization, public investments, and agriculture on human welfare in the Brazilian Amazonia. Land Use Policy, 65, 135-142.

Deo, K., Mandhata, S., Arif, P., Mishra, J. S., \& Bhatt, B. P. (2018). Direct seeded rice: an option for enhancing the productivity, improving resource use efficiency and minimize the production cost of the rice. Journal of AgriSearch, 5(3), 159-162.

Etana, D., \& Tolossa, D. (2017). Unemployment and food insecurity in urban Ethiopia. African Development Review, 29(1), 56-68.

Govindan, K. (2018). Sustainable consumption and production in the food supply chain: A conceptual framework. International Journal of Production Economics, 195, 419-431.

Guesmi, B., Serra, T., Radwan, A., \& Gil, J. M. (2018). Efficiency of Egyptian organic agriculture: A local maximum likelihood approach. Agribusiness, 34(2), 441-455.

Hasanah, Y., Hanum, H., \& Rusmarilin, H. (2019). Field School of Organic Farming as an Effort to Increase Organic Rice Production. Journal of Saintech Transfer, 2(2), 126-131.

Inwood, S. (2017). Agriculture, health insurance, human capital and economic development at the rural-urban-interface. Journal of Rural Studies, 54, 1-14.

Kim, J. B., Lee, H. H., \& Yang, H. C. (2014). Proposal of Eco-M Business Model: Specialty Store of Eco-friendly Agricultural Products Joined with Suburban Agriculture. Journal of Asian Finance, Economics and Business, 1(4), 15-21. https://doi. org/10.13106/jafeb.2014.vol1.no4.15.

Kuswanto, K., Alamsyah, Z., Armandelis, A., \& Zulfanetty, Z. (2019). The Impact of the Efficiency of Rubber Production on the Welfare of Rubber Farmers in Jambi Province. International Journal of Economics and Financial Issues, 9(2), 80. https:// doi.org/10.32479/ijefi.7503

Lambin, J. J., Chumpitaz, R., \& Schuiling, I. (2007). Market-driven management: Strategic and operational marketing. New York, NY: Macmillan International Higher Education.

Larson, B., Minten, B., \& Razafindralambo, R. (2006). Unravelling the linkages between the millennium development goals for poverty, education, access to water and household water use in developing countries: evidence from Madagascar. The Journal of Development Studies, 42(1), 22-40.

Mankiw, N. G. (2020). Principles of economics. Boston, MA: Cengage Learning.

Marja, R., Kleijn, D., Tscharntke, T., Klein,A. M., Frank, T., \& Batáry, P. (2019). Effectiveness of agri-environmental management on pollinators is moderated more by ecological contrast than by landscape structure or land-use intensity. Ecology letters, 22(9), 1493-1500.

Nazir, M. (2005). Research Method. Jakarta, Indonesia: Ghalia Indonesia. [Indonesian]

O'Connor, D., Boyle, P., Ilcan, S., \& Oliver, M. (2017). Living with insecurity: Food security, resilience, and the World Food Programme (WFP). Global Social Policy, 17(1), 3-20.

Olowu, G., Olaseinde-Williams, G. O., \& Bein, M. (2019). Does financial and agriculture sector development reduce unemployment rates? Evidence from Southern African countries. Agricultural Economics, 65(5), 223-231. 
Pearce, J. A., Robinson, R. B., \& Subramanian, R. (2000). Strategic management: Formulation, implementation, and control. Columbus, OH: Irwin/McGraw-Hill.

Rachmawati, A. M., Wulandari, D., \& Narmaditya, B. S. (2018). Financial Deepening and Income Inequality in Indonesia. Global Business Review, [Online First] https://doi. org/10.1177/0972150918811246

Purwanti, P., Susilo, E., \& Indrayani, E. (2020). Business Empowerment Program and Household Economic Welfare: Lesson from Indonesia. Journal of Asian Finance, Economics, and Business, 7(1), 313-320. https://doi.org/10.13106/ jafeb.2020.vol7.no1.313

Rana, J., \& Paul, J. (2017). Consumer behavior and purchase intention for organic food: A review and research agenda. Journal of Retailing and Consumer Services, 38, 157-165.

Rangkuti, F. (2001). SWOT Analysis of the Technique for Dissecting Business Cases. Jakarta, Indonesia: PT. Gramedia Pustaka Umum. [Indonesian]

Saediman, H., Aisa, S., Zani, M., Limi, M. A., \& Yusria, W. O. (2019). Food security status of households in a cassavagrowing village in Southeast Sulawesi, Indonesia. Journal of Agricultural Extension, 23(1), 199-209.

Sedyati, R. N., Djatmika, E. T., Wahyono, H., \& Utomo, S. H. (2019). The Business Alteration for Tobacco Farmers:
Lessons from Rural Area in Indonesia. Journal of Asian Finance, Economics and Business, 6(4), 281-286. https://doi. org/10.13106/jafeb.2019.vol6.no4.281

Soetriono, S., \& Suwandari, A. (2017). Factors That Influence the Income and Strategy for The Development of Koki Mas Fish in the Village of Wajak Lor, Boyolangu District, Tulungagung Regency. Journal of Social and Agricultural Economics, 9(2), 10-22. [Indonesian]

Soekartawi. (1995). Farm Analysis. Jakarta, Indonesia: Universitas Indonesia Press. [Indonesian]

TerAvest, D., Wandschneider, P. R., Thierfelder, C., \& Reganold, J. P. (2019). Diversifying conservation agriculture and conventional tillage cropping systems to improve the wellbeing of smallholder farmers in Malawi. Agricultural Systems, 171, 23-35.

Thufail, F. I. (2016). Regional Dynamics in a Decentralized Indonesia. Pacific Affairs, 89(1), 235-237.

Utami, H. D., \& Dian, M. (2019). Economic Performance on Small Holder Ettawah Cross Breed Goat Farming at Malang Indonesia. Egyptian Journal of Sheep and Goats Sciences, 14(1), 1-9.

Wildana, M. D. A., \& Alhabshi, S. M. S. J. (2018). Proposed Waqf Framework for Food Security and Price Stabilization Policy of Rice in Indonesia. Journal of Islamic Finance, 7(2), 70-85. 